\title{
Zika vírus e microcefalia nos discursos de mulheres no jornalismo e no Facebook
}

\author{
Zika virus and microcephaly in women's speeches in journalism and \\ Facebook

\section{El virus del Zika y la microcefalia en los discursos de las mujeres en el periodismo y Facebook}

\author{
Rayza Sarmento ${ }^{1, a}$ \\ rayzasarmento@gmail.com | https://orcid.org/0000-0002-9817-7941 \\ Paula Dornelas ${ }^{2, b}$ \\ pauladdornelas@gmail.com | https://orcid.org/0000-0002-2394-2370 \\ Maria Ligia Ganacim Granado Rodrigues Elias ${ }^{3, c}$ \\ ligiagrananado@gmail.com | https://orcid.org/0000-0003-3645-9131 \\ Amanda Rocha ${ }^{4, d}$ \\ amandarch22@gmail.com | https://orcid.org/0000-0003-1825-9574
}

\footnotetext{
${ }^{1}$ Universidade Federal de Viçosa, Departamento de Ciências Sociais. Viçosa, MG, Brasil.

2 Universidade Federal de Minas Gerais, Programa de Pós-Graduação em Ciência Política. Belo Horizonte, MG, Brasil.

${ }^{3}$ Universidade Cesumar. Maringá, PR, Brasil.

${ }^{4}$ Universidade Federal de Viçosa, Curso de Ciências Sociais. Viçosa, MG, Brasil.

a Doutorado em Ciência Política pela Universidade Federal de Minas Gerais.

b Mestrado em Ciência Política pela Universidade Federal de Minas Gerais.

c Doutorado em Ciência Política pela Universidade de São Paulo.

d Graduanda em Ciências Sociais pela Universidade Federal de Viçosa.
}

\section{RESUMO}

A epidemia de Zika vírus que assolou o Brasil no final de 2015 trouxe desafios e graves consequências para a população em diferentes regiões e contextos, assumindo destaque na cobertura midiática à época. As mulheres, sobretudo as gestantes e mães, foram fortemente impactadas pela epidemia, principalmente após a comprovação da relação entre a infecção pelo Zika e o nascimento de bebês com microcefalia. Apesar disso, essas mulheres foram invisibilizadas na cobertura midiática da emergência sanitária, tendo sido pouco ouvidas sobre um tema que afeta(va) diretamente as suas vivências e as de seus filhos e filhas. Nesse sentido, o artigo reflete sobre a fala pública das mulheres, com base em discussões da teoria política feminista e da análise empírica de dois espaços de comunicação on-line: o jornal Folha de S.Paulo e a página de Facebook de uma associação de mulheres, a União de Mães de Anjos (UMA). Observamos como diversos silenciamentos se fazem presentes nos espaços midiáticos, como as dinâmicas do cuidado se manifestam e são permeadas por quadros de desigualdade, e como as resistências, apesar desses cenários, se constroem cotidianamente entre mulheres.

Palavras-chave: Mulheres; Jornalismo; Zika vírus; Internet; Microcefalia. 


\section{ABSTRACT}

The Zika virus epidemic that hit Brazil at the end of 2015 brought challenges and serious consequences for the population in different regions and contexts of the country, gaining prominence in the media coverage at the time. Women, especially pregnant women and mothers, were strongly affected by the epidemic, especially after the confirmation of the relationship between Zika infection and the birth of babies with microcephaly. Despite this, these women were made invisible in the media coverage of the health emergency, having been not enough heard about a topic that directly affects their experiences and those of their sons and daughters. In this sense, the article reflects on the public speech of women, based on discussions of feminist political theory and the empirical analysis of two online communication spaces: the Folha de S.Paulo newspaper and the Facebook page of a women's association, the União de Mães de Anjos (UMA). We observed how different silences are present in the media spaces, how the dynamics of care are manifested and are permeated by situations of inequality, and how resistance, despite these scenarios, is built daily among women.

Keywords: Women; Journalism; Zika virus; Internet; Microcephaly.

\section{RESUMEN}

La epidemia del virus Zika que afectó a Brasil a finales de 2015 trajo desafíos y graves consecuencias para la población en diferentes regiones y contextos, asumiendo protagonismo en la cobertura mediática de la época. Las mujeres, especialmente las embarazadas y las madres, fueron fuertemente afectadas por la epidemia, especialmente después que fue probada la relación entre la infección por Zika y el nacimiento de bebés con microcefalia. Pese a ello, estas mujeres quedaron invisibilizadas en la cobertura mediática de la emergencia sanitaria, habiendo sido poco escuchadas sobre un tema que afecta directamente sus vivencias y las de sus hijos e hijas. En este sentido, el artículo reflexiona sobre el discurso público de las mujeres, a partir de discusiones de la teoría política feminista y el análisis empírico de dos ámbitos de la comunicación online: el periódico Folha de S.Paulo y la página de Facebook de una asociación de mujeres, la União de Mães de Anjos (UMA). Observamos como los diferentes silencios están presentes en los espacios mediáticos, como las dinámicas del cuidado se manifiestan y están permeadas por situaciones de desigualdad, y como la resistencia, a pesar de estos escenarios, se construye diariamente entre las mujeres.

Palabras clave: Mujeres; Periodismo; Zika virus; Internet; Microcefalia.

Este artigo compõe o dossiê Feminismos: perspectivas em comunicação e informação em saúde, parte 1.

Contribuição dos autores:

Concepção e desenho do estudo: Rayza Sarmento, Paula Dornelas e Maria Ligia Elias.

Aquisição, análise ou interpretação dos dados: Rayza Sarmento, Paula Dornelas, Maria Ligia Elias e Amanda Rocha.

Redação do manuscrito: Rayza Sarmento, Paula Dornelas, Maria Ligia Elias e Amanda Rocha.

Revisão crítica do conteúdo intelectual: Rayza Sarmento, Paula Dornelas e Maria Ligia Elias.

Declaração de conflito de interesses: não há.

Fontes de financiamento: parte da pesquisa foi desenvolvida com Bolsa PIBIC CNPq.

Considerações éticas: não há.

Agradecimentos/Contribuições adicionais: não há.

Histórico do artigo: submetido: 02 mar. 2021 | aceito: 31 maio 2021 | publicado: 30 jun. 2021.

Apresentação anterior: não houve.

Licença CC BY-NC atribuição não comercial. Com essa licença é permitido acessar, baixar (download), copiar, imprimir, compartilhar, reutilizar e distribuir os artigos, desde que para uso não comercial e com a citação da fonte, conferindo os devidos créditos de autoria e menção à Reciis. Nesses casos, nenhuma permissão é necessária por parte dos autores ou dos editores. 


\section{INTRODUÇÃO}

No final de 2015, o Brasil passou por uma epidemia de Zika vírus. O mosquito vetor já era conhecido do sistema de saúde e da população brasileira, o Aedes aegypti, mesmo transmissor da dengue, chikungunya e, em áreas urbanas, da febre amarela. Os sintomas da doença tendem a ser leves, como dor de cabeça, dores nas articulações, vermelhidão e coceira nos olhos, com poucos casos de complicações. Na mesma época, sobretudo no Nordeste brasileiro, houve um aumento de nascimentos de crianças com problemas neurológicos e microcefalia. Em dezembro daquele ano, a Organização Mundial da Saúde (OMS) emitiu um alerta epidemiológico acerca da relação entre o Zika e a má formação congênita (PAHO, 2015), e pesquisadoras da Fundação Oswaldo Cruz (Fiocruz) desenvolveram um estudo controlado com mulheres grávidas com sintomas da doença, cujo resultado apontava desenvolvimento anormal nos fetos (BRASIL; PEREIRA JR; MOREIRA; NOGUEIRA, 2016).

Comprovada a relação entre a infecção pelo Zika em gestantes e o nascimento de bebês com microcefalia, a epidemia do Zika vírus se tornou pauta recorrente no jornalismo brasileiro e desde então vem sendo analisada sob diferentes enfoques (PORTO; COSTA, 2017; MOREIRA; MENDES; NASCIMENTO, 2018; CASTILHOS; ALMEIDA, 2020). Este artigo se volta para essa cobertura a partir de um foco específico: a forma como as mulheres grávidas e/ou mães de bebês com doenças decorrentes do Zika, como a microcefalia, foram ouvidas e falaram acerca da descoberta e da vivência em relação ao vírus e as consequências para seus filhos e filhas. Para isso, desenvolvemos uma discussão interdisciplinar em que mobilizamos temas da teoria política feminista, combinando-a com a análise empírica de dois espaços de comunicação on-line (um jornal e uma rede social) para, assim, elaborarmos uma reflexão sobre a fala pública das mulheres, seus silenciamentos, mas também suas resistências.

Empiricamente, movemos-nos em duas direções. A primeira delas se volta para o exame das notícias em que mães foram ouvidas como fontes, especificamente os textos publicados no site do jornal Folha de S.Paulo, nos primeiros três meses da epidemia (entre novembro de 2015 e janeiro de 2016). Em um segundo momento, exploramos uma página do Facebook criada por um grupo de mães a fim de socializar suas experiências, a União de Mães de Anjos (UMA). Este artigo está estruturado, para além desta introdução, em quatro partes: uma revisão da literatura feminista que sustenta nossa discussão; a apresentação dos caminhos metodológicos da pesquisa; a análise dos dois espaços comunicativos on-line; bem como as considerações finais.

\section{MULHERES, FALA PÚBLICA E JUSTIÇA REPRODUTIVA}

A teoria política feminista tem apontado sistematicamente a exclusão e marginalização das mulheres da vida pública. A política institucional parece ser o exemplo mais evidente dessa ausência, com um número diminuto de representantes mulheres. Para além desses espaços formais, a ocupação da esfera pública por mulheres de forma organizada, em movimentos feministas, ou individualmente, é marcada por uma série de constrangimentos (FRASER, 1990; YOUNG, 2000). Essa situação relaciona-se a uma clássica divisão dos espaços públicos e privados muito questionada pelos estudos feministas. Historicamente os espaços públicos são ocupados por homens e são acessados e mantidos por dinâmicas de poder; já os espaços privados estão associados às mulheres. São eles que permitem, conforme sustentam autoras como Pateman (1993), que os primeiros existam. As formas de organização da agência masculina no mundo público (a exemplo da atuação política e profissional) são fruto de privações e desigualdades que se processam no privado.

A expressão pública a partir da fala - da oportunidade de ser ouvida e visibilizada, sobretudo, nos produtos midiáticos - é mais um desses exemplos. A preocupação com as formas diferentes de visibilidade 
entre mulheres e homens atravessa o campo da Comunicação a partir dos estudos feministas de mídia (SARMENTO, 2018), que partem de algo já diagnosticado: a desigualdade no acesso e no enquadramento sobre mulheres em diferentes veículos, formatos e territorialidades (ROSS, 2010).

É com base nesses debates que buscamos compreender como as mulheres grávidas ou mães apareceram na cobertura do vírus Zika e da microcefalia no primeiro trimestre da epidemia, quando o tema estava em ampla evidência nos meios de comunicação. Partimos da compreensão política das mulheres como um grupo social, não homogêneo, marcado por intensas diferenças internas. Como parte de um grupo, elas estão sujeitas ao que Iris Young (1990) conceitua como opressão estrutural ou sistemática, não situada em conduta individual ou de um governo específico. Segundo a autora: “[...] sua causa está incorporada em normas não questionadas, em hábitos e símbolos, nos pressupostos subjacentes de regras institucionais e nas consequências coletivas de seguir estas regras” (YOUNG, 1990, p. 41, tradução nossa). Young pontua que a opressão é uma das formas de injustiça sofrida por grupos e que os estereótipos culturais e aqueles presentes nos meios de comunicação são parte desse problema. Young ainda assinala que são "nos processos normais da vida cotidiana" (1990, p. 75, tradução nossa) que as dinâmicas opressivas se atualizam.

Essas injustiças permanecem quando as formas de reação também são cerceadas. A supracitada invisibilidade ou ausência na política formal, diz Young (2000), em Inclusion and democracy - livro clássico da teoria política feminista -, é apenas uma das formas desse cerceamento. Sentir-se incluída é um princípio fundamental para se pensar a democracia para além de processos agregativos, mas a exclusão das mulheres tem sido um fenômeno frequente em várias arenas da vida social. Um primeiro tipo de exclusão discutido por Young (2000) é a exclusão 'externa', quando literalmente as portas para o debate público e para as arenas de decisão estão fechadas. A luta do movimento feminista brasileiro, ao longo de diferentes épocas, tem sido um exemplo de enfrentamento a esse tipo de exclusão, sobretudo a partir das denúncias de mecanismos formais e informais de afastamento de mulheres das decisões que lhes afetam (ALVAREZ, 2014; BIROLI, 2018). O segundo tipo de exclusão apresentado por Young (2000) é a exclusão 'interna', que ocorre quando as mulheres, mesmo incluídas nos espaços, não têm suas demandas plenamente ouvidas ou consideradas.

Mas isso não significa que as mulheres atravessam essas condições da mesma maneira. Por isso, faz-se necessário ter lentes interseccionais para compreender esses processos de forma mais abrangente. Exposta e discutida, principalmente, por intelectuais e ativistas do feminismo negro, a noção de interseccionalidade ${ }^{i}$ está centrada na ideia de que há um entrecruzamento de opressões que permeiam as experiências na vida social. Isso significa dizer que a análise das dominações e dos sistemas de opressão deve considerar não só as desigualdades de gênero, mas também sua articulação com dimensões como raça, classe, sexualidade, etnia, entre outros fatores, tendo em vista que há diferentes aspectos que posicionam os sujeitos de forma distinta na sociedade.

Nesse sentido, é importante compreender, como defende Kimberlé Crenshaw (2004, p. 11), "o que acontece quando diversas formas de discriminação se combinam e afetam as vidas de determinadas pessoas". Ao olhar para as exclusões internas e externas que atravessam as ações das mulheres e as impedem de ter suas vozes ouvidas, é importante considerar que esses processos de injustiça são marcados, também, por outras formas de discriminação que envolvem fatores como classe, regionalidade e raça, por exemplo, que afetam, ainda, as possibilidades de enfrentamento dessas situações de exclusão e injustiça. Desse modo, também é relevante considerar as estratégias de resistência - em dimensões macro e microssociais - que

i O termo 'interseccionalidade' foi cunhado pela intelectual afro-americana Kimberlé Crenshaw (1989), mas outras autoras (COLLINS, 2019; GONZALEZ, 1984; CARNEIRO, 2003) também abordam as dinâmicas de articulação das desigualdades com os aspectos de raça, classe e gênero em diferentes contextos. 
as mulheres e os grupos em situações sociais desvantajosas desenvolvem para lutar contra a dominação e a opressão.

Joaze Bernardino-Costa (2015) defende que a noção de interseccionalidade seja mobilizada não apenas para situar os diversos quadros de desigualdade, mas também para evidenciar os processos de luta construídos por grupos marginalizados. Ao defender uma ideia de interseccionalidade emancipadora, o autor chama atenção para a potência presente na articulação e solidariedade entre diversos grupos e movimentos na busca pela garantia de direitos. Assim, do mesmo modo que as dominações estão presentes no dia a dia, as resistências podem ser observadas em estratégias cotidianas e menos evidentes (SCOTT, 1990), que podem envolver discursos, gestos e práticas, visando o enfrentamento das opressões e formas de exclusão.

A relação entre formas sistemáticas de opressão atualizadas por mecanismos como os discursos midiáticos e as exclusões externas e internas, assim como as estratégias de resistência, nos ajuda a refletir sobre o objetivo principal deste trabalho, qual seja: a análise da expressão pública das mulheres por meio de suas falas. Observamos a seguir 'como' e 'se' as mulheres tiveram oportunidade de se expressar no contexto da epidemia do Zika vírus, uma vez que essa epidemia incide mais diretamente sobre as vidas e experiências femininas, relacionando-se diretamente com questões como direitos e justiça reprodutiva.

A infecção de gestantes pelo Zika vírus pode levar a problemas na formação do sistema nervoso do feto, acarretando diversas alterações e malformações (entre elas a microcefalia) denominadas Síndrome Congênita do Zika vírus (TEIXEIRA; DANTAS; CARVALHO; SILVA et al. 2020). Essa síndrome coloca as mulheres gestantes em um contexto em que diferentes questões sociais e políticas podem tornar alguns grupos ainda mais vulneráveis, reforçando as desigualdades em marcadores como classe, raça e regionalidade.

Condições adequadas de habitação e saneamento, além de acesso a informações sobre a prevenção, são determinantes nesse contexto - e por isso fazem com que mulheres periféricas do Norte e Nordeste sejam as mais atingidas (CARVALHO, 2017). De acordo com uma pesquisa desenvolvida pelo Instituto de Bioética (Anis), em Alagoas, o perfil das mulheres mais acometidas pela doença no estado é de mulheres jovens, pouco escolarizadas e dependentes de políticas públicas de saúde e de assistência social (DINIZ, 2017). Desvela-se, assim, que os problemas da epidemia se agravam em contextos mais periféricos e que tratar das questões ligadas à microcefalia e às síndromes pelo Zika vírus envolve pensar questões como direitos sexuais e reprodutivos dentro de uma perspectiva de justiça reprodutiva.

Justiça reprodutiva é um conceito difundido por feministas negras nos Estados Unidos nos anos 1990, mas cujas questões são também elaboradas no Brasil por feministas como Sueli Carneiro (2015) e Jurema Werneck (2016). A ideia da justiça reprodutiva, enquanto uma teoria e uma práxis interseccionais, não tem o objetivo de substituir a noção de direitos sexuais e reprodutivos como Direitos Humanos, mas, sim, de englobar a complexidade de fatores que possibilitem o exercício desses direitos (ROSS, 2017).

Esquematicamente, podemos dizer que direitos sexuais e reprodutivos consistem em um conjunto de direitos que envolvem princípios como integridade corporal, autonomia individual, igualdade e diversidade (CORRÊA; PETCHESKY, 1996) e por isso relacionam-se com questões como mortalidade materna, violência sexual, aborto, infecções sexualmente transmissíveis. A justiça reprodutiva abarca essas questões, mas também fundamenta-se criticamente em relação ao racismo e ao neoliberalismo que ameaçam a integridade física de mulheres negras e as condições para a dignidade reprodutiva delas.

Assim, a justiça reprodutiva envolve tanto demandas pelo direito de ter condições de gerar um filho quanto o direito de não o ter, seja por uso de métodos contraceptivos, seja pelo direito ao aborto. Além disso, a justiça reprodutiva reivindica que mães, pais e cuidadores de crianças tenham acesso a ambientes seguros, saudáveis e livres de violência por parte de indivíduos ou do Estado (ROSS, 2017). Dessa forma, a justiça 
reprodutiva não só se envolve com questões de prestação de serviços de saúde reprodutiva, com demandas por direitos e litígios, como também prescreve que essas questões sejam entendidas considerando-se as dominações estruturais e interseccionais que afetam as mulheres negras e as mais vulneráveis socialmente (CARVALHO; ELIAS, 2020).

Trata-se de uma perspectiva que equaciona a luta por direitos e a luta pelas condições de exercício justo da vida sexual e reprodutiva. A justiça reprodutiva também aponta para a necessidade de se reconhecer o quanto mulheres negras e periféricas têm tido pouco acesso às práticas justas de cuidado e à atenção da saúde e da maternidade, sendo imprescindíveis, portanto, um entendimento dessas desigualdades e um esforço para mitigá-las.

O conjunto de textos analisados traz à cena pública aspectos desses complexos processos que envolvem a síndrome do Zika vírus, a partir da produção de discursos, seja no jornalismo, seja no Facebook. As mulheres, como veremos a seguir, são menos ouvidas que os especialistas. É importante mencionar que debates importantes, como o da saúde e o da justiça reprodutiva, incluindo a questão do aborto, ainda não são trazidos e interpretados à luz das experiências das mulheres, sobretudo, das grávidas quando olhamos especificamente do corpus jornalístico analisado nesta pesquisa.

\section{CAMINHOS METODOLÓGICOS"}

Para nossa análise, começamos com a coleta das notícias do site da Folha de S.Paulo entre 01/11/2015 e 31/01/2016. A escolha deste veículo on-line se dá pelo fato de ser um dos mais acessados portais de notícias nacionais, vinculando-se assim à longa tradição impressa do periódico, que remonta aos anos 1920. No âmbito on-line, também se trata de um dos primeiros portais jornalísticos, desde os anos de 1990. Editorialmente, afirma-se como independente de grupos ou partidos políticos, mas tem alternado posições em distintos momentos da história brasileira recente (PAIXÃO, 2018).

Utilizamos o mecanismo de busca da plataforma com a palavra-chave 'microcefalia'. A busca por esse termo, e não de forma mais ampla por 'Zika', por exemplo, se dá intencionalmente, pois buscamos discutir a questão da justiça reprodutiva - a partir das ocorrências de gravidez ou parto com suspeita ou confirmação de microcefalia. Nesse sentido, ressaltamos que outras palavras-chave certamente levariam a resultados diferentes dos apresentados aqui.

Inicialmente, tivemos 270 resultados, mas foram excluídos: editoriais, notas em colunas (por se tratar de conteúdo de caráter mais opinativo) e notícias internacionais (a fim de focarmos no cenário brasileiro) -, o que nos levou a um corpus de 176 textos. Construímos um banco de dados com as seguintes variáveis: título, link, data, texto, tipo de texto (reportagem, notícia ou entrevista), presença e número de fontes, tipos de fontes (tais como Legislativo, Executivo, Judiciário, mulheres grávidas, pais de crianças com microcefalia, profissionais da área da saúde, especialistas, sociedade civil, grávidas e mães de crianças com microcefalia). Também verificamos se a matéria tinha fotos e como tais imagens apresentavam as mães e crianças.

A partir da construção desse banco de dados, selecionamos para esta análise apenas as matérias em que mães de bebês com microcefalia e/ou grávidas foram ouvidas, totalizando 14,20\% do corpus coletado, ou seja, apenas 25 textos. ${ }^{\text {iii }}$ Este número já revela um dado importante: embora não possamos falar de um silenciamento absoluto, é pequena a presença da voz dessas mulheres no primeiro trimestre de cobertura midiática sobre um tema que as afeta diretamente.

Entre as fontes mobilizadas nos textos destacam-se o Executivo, sobretudo o Ministério da Saúde, com 43,8\%; profissionais da área saúde com 31,3\%; seguidos dos especialistas ligados a centros de pesquisa

ii Informamos que os bancos de dados e o livro de códigos construídos nesta pesquisa estarão à disposição para quaisquer pesquisadores(as), a partir de solicitação por $e$-mail.

iii Pode haver mais de uma mulher ouvida no mesmo texto. 
e universidades (21\%). Há poucas matérias com fontes da sociedade civil $(6,3 \%)$ e apenas quatro textos ouvindo homens na condição de pais de bebê ainda em gestação ou já nascidos (2,3\%).

Já a página do Facebook chamada UMA - União de Mães de Anjos foi fundada em dezembro de 2015 por duas mulheres que se conheceram na fila do Hospital Oswaldo Cruz, em Pernambuco, um dos estados com maior incidência de casos da doença. ${ }^{\text {iv }}$ As duas se identificaram a partir das vivências sobre maternidade e microcefalia e criaram um grupo na plataforma de mensagens WhatsApp para compartilhar experiências. De acordo a descrição da fanpage, depois dessa primeira articulação e a partir das demandas de outras mães, elas criaram a página UMA, como uma associação, que hoje auxilia "mais de 300 mães e famílias em todo o estado de Pernambuco, com o principal alvo de construir uma política de atendimento com qualidade para esses bebês vítimas de um descaso público, vítimas do Zika” (UMA, 2019). No site da associação, são relatadas as várias frentes de atuação e conquistas: a busca por colocar em postos de saúde a vacina dTpa, evitando febre nos bebês e convulsões decorrentes; a luta pela contratação de profissionais, como neuropediatras; a criação de parcerias com várias faculdades para a realização de terapias diversas; e a prioridade no recebimento do Minha Casa, Minha Vida para famílias vitimadas pela Zika.

A escolha da página da organização como um dos materiais a ser analisado se dá pela citação constante, até mesmo na imprensa tradicional, da UMA como uma das poucas organizações que agregam mães de crianças com microcefalia. Além disso, conforme já enunciado anteriormente, a pesquisa busca observar a comunicação produzida diretamente, sem mediações, por essas mulheres.

A coleta dos posts do Facebook da UMA foi realizada por meio do aplicativo Netvizz, que gera uma planilha, a partir de um tempo determinado, com publicações, fotos, interações, comentários, entre outras informações. O período estabelecido para a coleta foi de dezembro de 2015 a dezembro de $2017^{\mathrm{v}}$, cobrindo assim dois anos de postagens a partir da visibilidade nacional do surto de microcefalia, somando-se 625 casos, entre vídeos, fotos, links e compartilhamentos externos. Foram recolhidas as médias de curtidas, as reações e os compartilhamentos, além dos textos e das imagens dos posts. O banco de dados gerado pelo Netvizz contém tipo de postagem, link, texto, imagens, data e hora, números de curtidas, comentários, reações. Os comentários não foram coletados. Para este artigo, trabalharemos com os dez posts com maior número de interações, a partir da soma dessas variáveis.

\section{ANÁLISE}

A observação de duas dinâmicas on-line distintas relaciona-se com os debates feministas que trouxemos nas seções anteriores acerca da necessidade de se conhecer as condições de falas públicas de mulheres. No jornal, elas são acionadas como fontes, partes fundamentais da construção de conteúdo noticioso e fartamente discutidas nos estudos de jornalismo (DUARTE, 2010; LAGE, 2001). Aqui nos interessa investigar os espaços coconstruídos nos jornais com as fontes ouvidas, o que é trazido ao texto jornalístico a partir do contato com essas mulheres, considerando-se como o jornalismo se constrói ou não nessas dinâmicas político-ideológicas desiguais, sem prescindir das questões de gênero (MIGUEL; BIROLI, 2011).

iv Entre 2015 e 2020, foram notificados ao Ministério da Saúde 19.622 casos suspeitos de Síndrome Congênita Associada à Infecção pelo vírus Zika (SCZ), dos quais $18,2 \%$ foram confirmados. A ocorrência de nascidos vivos com SCZ se deu, principalmente, nos anos de 2015 e 2016, com maior concentração de casos na região Nordeste do país. Entre os casos confirmados de SCZ até 2019, $78,3 \%$ eram representados por recém-nascidos com microcefalia. Entre 2015 e 2019, a região Nordeste também foi a que mais notificou óbitos relacionados à SCZ, sendo Pernambuco o estado com maior notificação de óbitos (232) fetais, neonatais e infantis em decorrência da síndrome. Em 2020, nasceram 20 crianças confirmadas com SCZ, a maior parte residente na região Sudeste, no estado de Minas Gerais. Para mais informações, ver Brasil (2021, 2019).

v A diferença entre o tempo de coleta das notícias on-line e dos posts na página da UMA se dá em função do volume de dados disponíveis em cada um dos espaços comunicacionais. Nos três primeiros meses da epidemia, havia maior concentração de textos no jornalismo se comparado à página, em função das notícias diárias sobre Zika e microcefalia. Como a comunicação da UMA se estruturava junto a sua própria atuação política, entendemos que o acompanhamento de dois anos traria um conjunto de textos maior que possibilitaria a análise, dado que muitos dos posts se referem aos eventos ou às 'vaquinhas virtuais'. 
Os estudos acerca das fontes jornalísticas preocupados com as dimensões de gênero, informa Ross (2010), têm mostrado que as mulheres são menos ouvidas na condição de especialistas e na condição de pessoas comuns, acerca de comportamento eleitoral ou de intenção de voto, por exemplo. Para Gallagher (2001, p. 120, tradução nossa), observar a forma como as mulheres falam é um caminho importante dos estudos feministas de mídia e dos projetos de intervenção, que devem sempre questionar: "Elas são representadas de uma forma que lhes permita falar com dignidade e autoridade?”.

Já na análise da página da UMA, buscamos compreender o que ela expõe por si mesma, sem a mediação dos media, apoiadas em ampla discussão sobre os potenciais das plataformas on-line para a expressão pública de sujeitos e grupos. Segundo Maia (2008, p. 348), é necessário observar as diversas iniciativas empíricas em "que associações com propósitos democráticos utilizam os recursos da internet para adquirir competência crítica e política, mobilizar a ação e interagir com os agentes do centro do sistema político”.

Analiticamente, nós nos inspiramos nas construções sobre análise do discurso, alinhadas às premissas discutidas por Gill (2002). Nesse sentido, é preciso enfatizar que não trabalhamos com uma abordagem estritamente linguística. Fairclough (2001, p. 90) define o discurso como: "o uso de linguagem como forma de prática social e não como atividade puramente individual [...] um modo de ação, uma forma em que as pessoas podem agir sobre o mundo". Assim, estamos mais distantes de uma abordagem mais estruturalista, tal como de Pêcheux, que "considera a prática discursiva em termos de um modelo de causalidade mecânica" (FAIRCLOUGH, 2001, p. 94). Na perspectiva faircloughiana, os discursos não apenas agem na representação do mundo, mas também no seu processo de significação, construindo-o (FAIRCLOUGH, 2001, p. 91).

Embora haja diferentes vertentes de analistas do discurso, Gill (2002, p. 224) expõe que, em comum, há "uma rejeição da noção realista de que a linguagem é simplesmente um meio neutro de refletir, ou descrever o mundo, e uma convicção da importância central do discurso na construção da vida social". A autora chama a atenção para a relação entre o texto e o seu contexto de inserção. O exercício da análise do discurso está ligado também aos objetivos e à discussão teórica do sujeito, sendo que em algumas abordagens esse processo se mostra "sempre indefinível, ela nunca pode ser captada por descrições de esquemas de codificação, hipóteses e esquemas analíticos” (GILL, 2002, p. 248).

Desenvolvemos nossa análise considerando as notícias que privilegiaram falas de mulheres e os posts da UMA como nossas unidades de análise - sem perder de vista como essas falas, dispostas nesses lugares, dialogam com os debates feministas que apresentamos anteriormente. Assim, é importante ressaltar que não compreendemos o jornalismo ou a página criada pelas mães como detentores únicos do discurso, mas parte de uma teia em que tal construção se insere. Conforme alertam Jáuregui e Vieira (2014, p. 73), é importante "prezar pela identificação do feixe de relações que permitem ao discurso existir".

Também nos mantivemos atentas para o que não é expressamente identificável. Sobre isso, Gill (2002, p. 248) enfatiza que os analistas do discursos "devem também estar sensíveis àquilo que não é dito - e aos silêncios. Isso, por sua vez, exige uma consciência aprimorada das tendências e dos contextos sociais, políticos e culturais aos quais os textos se referem".

Passemos, a seguir, para nosso primeiro conjunto de textos, os noticiosos.

\section{Notícias do site da Folha de S.Paulo cujas fontes são mulheres grávidas e/ou mães}

A leitura repetida e teoricamente orientada das notícias com a presença de mulheres mães e/ou grávidas revelou três grandes vieses discursivos sobre o Zika e a microcefalia no jornal em tela.

O 'primeiro' deles aborda a doença da mãe (o Zika) e as consequências para o bebê (sobretudo a microcefalia) sob um viés do 'medo' dessas mulheres acerca de como será o parto, o nascimento, a vida das suas crianças. Durante os três meses de análise, o jornal explora essa preocupação ilustrando com casos 
como as mulheres desconfiaram, descobriram ou se informaram sobre o Zika vírus e as suas consequências. A procura por informações, as várias falas sobre a circunferência da cabeça das crianças e a preocupação com o futuro estão presentes nos textos nos quais essas mulheres são mobilizadas como fontes.

No trecho da notícia 1 (NOT 1), a seguir, a fala de uma das mães traz um sentimento de culpa, ao se perguntar se foi alguma coisa que ela fez para que o bebê desenvolvesse a doença. No texto seguinte (NOT 2), falas sobre "pânico", "preocupação" e "tortura" são expressas pelas mulheres, que buscaram a possibilidade de antecipação do parto. A tensão e o alívio após a descoberta de que as crianças não tinham o problema também acompanhou várias das mulheres, como percebido no trecho de NOT 3.

NOT 1: Uma ultrassonografia, feita aos sete meses de gestação, levou Aline Ferreira a encarar a suspeita de que havia algo errado com o desenvolvimento de seu bebê. Moradora de um pequeno distrito do município de Vertentes, no interior de Pernambuco, a estudante foi encaminhada a um hospital de referência em Recife. Lá, após exames, veio a confirmação: a criança tinha sinais de malformação do crânio, a microcefalia. Logo as dúvidas sobre a gestação precoce - Aline tem 15 anos - deram lugar a outras dúvidas: sobre a saúde da criança e sobre o que teria causado o problema no menino. "- Pensei: foi alguma coisa que eu fiz? Algo que eu comi e fez mal?”, conta. (CANCIAN; ANZIELLI, 2015)

NOT 2: “- Doutor, e a cabeça?” Com o surto de microcefalia que atinge o Nordeste, essa tem sido a primeira pergunta das gestantes, quando chegam para os ultrassons de rotina. [...] Em Salvador (BA), Luana, 32 anos e na $27^{\mathrm{a}}$ semana de gestação, conta que fez três ultrassons só neste mês para se certificar de que o bebê está bem. “- Minha médica é contra, mas estou em pânico.” [...] Talita França, 32, relata que não para de pensar nos casos de microcefalia. Grávida de 22 semanas, ela só anda de calça comprida, camisas de manga longa e com muito repelente no corpo. Na última terça, ao fazer o ultrassom morfológico, chorou ao ouvir da médica que estava tudo bem. "- Estou aliviada, mas não despreocupada. Até o final da gestação vai ser essa tortura.” Luciane Brito, 38, vive angústia semelhante. "- Não estou dormindo direito. Liguei para a minha médica pedindo para antecipar o parto. Estou na $37^{\mathrm{a}}$ semana, acho que está bom, mas ela discorda.” (COLLUCCI, 2015)

NOT 3: Foram poucos minutos de espera na fila na tarde de sábado (5), depois de uma semana de tensão, mas o resultado compensou para o casal Suziane e Lázaro dos Santos. Inscritos no mutirão de diagnóstico de bebês, em Salvador, os dois ficaram aliviados após saberem que a filha, um bebê de quatro meses, não tem microcefalia. Eles e outro grupo de pessoas levaram os filhos para fazer exames ultrassonográficos na Escola de Imagem Caliper. Lá, os diagnósticos foram acompanhados por especialistas. “- Tive o vírus Zika no oitavo mês de gestação e, claro, estou preocupada”, disse Suziane à Folha enquanto estava na fila. A boa notícia foi dada pelo médico e professor Kleber Pimentel, especialista em ultrassonografia geral.

(REIS, 2015).

Um 'segundo viés discursivo' se relaciona às 'dinâmicas de cuidado' que atravessam majoritariamente a vida feminina. Com a descoberta da condição das crianças, foram vários os relatos de mulheres que passaram a se dedicar estritamente ao cuidado com seus filhos, por vezes na busca de uma vida menos adversa para a criança. Os trechos de NOT 4 e NOT 5 trazem perspectivas e condições distintas sobre essa questão. Na primeira, as condições financeiras e materiais permitem a busca por uma série de profissionais mesmo para quem largou o emprego; na segunda, o abandono do companheiro exacerba ainda mais o trabalho da reprodução, também visto em NOT 6.

NOT 4: Deixei o meu trabalho [ela tem uma loja de calçados] para cuidar dela. Estou correndo atrás de todas as possibilidades de reabilitação, neuro, fisioterapeuta, fonoaudiólogo. Sou confiante, acredito muito na minha filha. Não escuto mais nada sobre as deficiências, tento pensar no que ela pode conseguir. Os médicos dão um diagnóstico, mas Deus dá outro. [...] Meu maior desespero era que minha filha não sobrevivesse. Não tenho vergonha dela. Pelo contrário, saio com ela nas ruas, não a escondo. Às vezes, os primeiros a terem preconceito são os próprios pais. Eu olho para a minha filha e vejo uma coisa linda, toda perfeitinha. (COLLUCCI, 2015).

NOT 5: Mal se recuperou do baque de saber que o filho Daniel nasceu com microcefalia, e a auxiliar de padeiro Jaqueline Vieira, 25, sofreu outro revés: o marido a abandonou. “- Depois que meu filho nasceu com 29,5 cm [de perímetro cefálico], o pai nos deixou. Só manda dinheiro, mas não quer saber muito dele. Estou profundamente triste”, diz. Ela é uma das mães de bebês que nasceram com microcefalia supostamente causada pelo vírus Zika que está à espera de atendimento psicológico em Pernambuco [...]. A necessidade do atendimento é reforçada pela assistente social Camilla Cabral, da Fundação Altino 
Ventura, entidade que prestará apoio psicológico às famílias. “[As mães] - chegam um pouco frustradas e com medo. Muitas entram em depressão. Teve até um caso de uma mãe que não queria nem sequer amamentar", conta. (NUNES, 2016)

NOT 6: A recepcionista Danielle Santos, 29, trouxe o filho Juan Pedro, de dois meses, para fazer exames oftalmológicos e neurológicos. “- O Juan chora muito, só para quando está no banho”, diz Danielle. O pai da criança abandonou Danielle, quando Juan tinha um mês. Ela tem ainda uma filha de 11 anos, Jennifer, que ajuda a cuidar do irmão. Os bebês com microcefalia costumam ser muito irritadiços, chegam a chorar durante horas, ininterruptamente, e têm problemas para segurar o pescoço e fazer outros movimentos, o que varia segundo a gravidade do caso. (MELO, 2016)

Isso se soma a um dado também relevante, que aponta que os pais das crianças foram ouvidos em apenas quatro textos, ou 2,3\% do corpus coletado. Os homens genitores das crianças não aparecem com frequência nos textos nem são confrontados diretamente sobre as dinâmicas de cuidado.

O abandono do companheiro relatado por muitas mulheres e a ausência das vozes dos pais nas matérias analisadas evidenciam outras dinâmicas relacionadas ao cuidado e aos papéis de gênero socialmente construídos. Como aponta Hirata (2016, 2011), as atividades ligadas ao cuidado, desempenhadas tanto nos espaços domésticos quanto no mercado de trabalho, são majoritariamente exercidas por mulheres e se inserem no amplo cenário de divisão sexual do trabalho. A ideia de que mulheres são essencialmente aptas a exercer atividades de cuidado e que essa responsabilidade é um elemento 'natural' feminino posiciona e atribui às mulheres as tarefas vinculadas ao cuidar e, nos casos analisados aqui, delega unicamente às mães a responsabilidade pelo cuidado com os filhos. Enquanto elas deixam o mercado de trabalho para se dedicar unicamente às dinâmicas com as crianças, muitos genitores se eximem dessas atividades. A responsabilização deles é invisibilizada também nos textos, nos quais poucas vezes são consultados. Essa alocação diferenciada de papéis e responsabilidades traz, contudo, custos diferentes para as mulheres e os homens, além de reforçar desigualdades e assimetrias, principalmente se considerarmos raça e classe, como abordaremos na análise do terceiro viés discursivo, a seguir.

Por outro lado, as dinâmicas do cuidado implicam, também, formas de resistência. O trecho a seguir expõe a dimensão do reconhecimento e da valorização daqueles que são dependentes do cuidado, evidenciando como a articulação entre aquelas que são responsáveis por essas tarefas foi importante para tal. O enfrentamento dos problemas cotidianos se dá, nesse âmbito, pela união entre as mães, que partilham vivências comuns e trocam experiências, dicas e relatos sobre os diagnósticos, além de histórias sobre como as crianças estão respondendo aos estímulos.

NOT 8: Quando começou a acompanhar o noticiário sobre a epidemia de microcefalia que foi descoberta no Nordeste brasileiro, em outubro de 2015, a funcionária pública amazonense Viviane Lima preocupou-se com as mães que, como ela, enfrentariam a condição. "- Só se fala dos problemas de saúde das crianças, mas o que acontece agora? Ninguém falava das possibilidades, do que é possível alcançar”, disse. Viviane, 35, é mãe de duas adolescentes com microcefalia e, desde que decidiu contar sua história no Facebook, foi procurada por mulheres de todo o Brasil para dar conselhos e dicas de estímulo às crianças. Agora, reúne mais de 70 mães em um grupo de WhatsApp. “- Eu tento mostrar que elas vão conseguir resultado com a estimulação das crianças. Digo que eu não aceitei o diagnóstico que me deram, que fui atrás do que poderia fazer. Mando vídeos das minhas meninas em casa, falando e cantando.” (COSTA, 2016).

Com estreita ligação com o viés anterior, o 'terceiro viés discursivo' aponta para as 'desigualdades econômicas, mas também interseccionais' entre as mulheres no que tange à proteção do Zika. As notícias abordam como mulheres com poder aquisitivo tiveram suas vidas alteradas por conta da doença ou da preocupação com ela. O cancelamento de viagens (o aumento dos casos se deu próximo às festas de final de ano) para o Nordeste ou a busca por repelentes menos tóxicos deixam explícitas essas diferenças (NOT 7 e NOT 2). 
NOT 7: O repelente virou item de bolsa obrigatório, as roupas compridas saíram do armário em pleno calor de dezembro e telas contra insetos entraram na lista de desejos de consumo. Tudo para evitar o Aedes aegypti, mosquito que transmite dengue, chikungunya e, agora, também a Zika. A rotina e as preocupações das gestantes mudaram após a proliferação de casos de microcefalia ligados ao vírus Zika no país [...]. “- Passo repelente toda hora”, diz a estilista Susan Feldman, 33, grávida de cinco meses e dona de quatro exemplares do produto. Seis casos de microcefalia possivelmente ligados ao Zika são investigados em São Paulo, onde ela mora, enquanto o Nordeste concentra o maior número de suspeitas. Por isso, ela desistiu de ir à Bahia no fim do ano e resolveu comprar passagens para Miami, nos EUA. "- Não custa nada ficar em casa durante um ano", exagera Luciana Almeida, 36, coordenadora de fisioterapia do Instituto do Câncer do Estado de SP e grávida de gêmeos. Ela conta que demorou cinco anos para conseguir engravidar, de forma natural. Agora, diz, "- Faço de tudo e mais um pouco" para proteger a gravidez. Tudo e mais um pouco: repelente na bolsa, repelentes eletrônicos nas tomadas de casa, roupas compridas ("mesmo no calor"), tela nas janelas do apartamento. A viagem ao sítio, no interior de São Paulo, deu lugar ao Réveillon na capital. Há exceções, no entanto. A advogada Simone Rossi, 40, diz que não cancelará a viagem à Bahia. “- Se eu tiver que pegar lá ou aqui, vou pegar. É só não dar asas ao azar.” (GRANGNANI, 2015)

NOT 2: Catarina Menezes, 33, grávida de oito semanas, esperava, aflita, o seu primeiro ultrassom. "- Se eu soubesse desse Zika, não engravidaria agora. Na TV, eles dizem: 'Evitem engravidar, evitem o Nordeste.' E o que fazemos, nós, grávidas que vivemos aqui?" (COLLUCCI, 2015)

Os casos analisados evidenciam como as assimetrias se dão não somente pela responsabilização única das mulheres pelo cuidado, mas são reforçadas por desigualdades socioeconômicas e regionais, que afetam as mães de modo distinto. Se algumas mudaram a rota do Réveillon para evitar a infecção pelo Zika, outras não tiveram a possibilidade de sair do local onde viviam para evitar o contágio. Nesse aspecto, como aponta Joan Tronto (2007) sobre as dinâmicas de cuidado, o acesso desigual a recursos acaba prejudicando muitas pessoas, o que reforça assimetrias.

\section{Os posts do Facebook da União de Mães de Anjos}

A fim de observarmos um espaço de comunicação construído pelas mães acometidas pela Zika e com bebês com microcefalia, analisamos as postagens da página União de Mães de Anjos no Facebook, a UMA. Nosso objetivo não é necessariamente comparar esse material com o jornalismo, mas identificar quais os discursos disponíveis em uma plataforma gerenciada por elas mesmas. Dado que o universo de postagens era muito extenso (625 postagens), calculamos a partir das variáveis de interação os dez posts com maior número de engajamento total. Essa atribuição de um número de posts nos ajuda a olhar mais detidamente para as construções discursivas. Entre os dez posts mais curtidos, dois são de pedidos de doação ('vaquinha virtual'): um trata-se de repost de um conteúdo do Unicef e outro é uma postagem de um vídeo do jornalista e apresentador Chico Pinheiro, 'dando força' às mães. Focamos nos posts que, além de fotos ou vídeos, traziam textos escritos pelas mulheres. Assim, buscamos analisar nesse conjunto de dez posts com maior engajamento, seis posts que trazem dimensões interessantes para a discussão sobre a fala pública das mulheres.

Com fotos das crianças em carrinhos e com adereços infantis, dois posts entre os selecionados trazem textos sobre a partida dos bebês. As mulheres se denominam como 'mãe especial' e as crianças são tratadas como 'anjos' que trazem 'lições'.

A dor e as incertezas de ser uma mãe especial têm disso... Vai com Deus, Vitória, que os anjos já te receberam com toda alegria do mundo. Nossos sentimentos e nossa dor (Escrevendo e me tremendo) aos pais adotivos, Kelly e Josimar, que abraçaram a Vitória em um abrigo e lhe deram todo amor, cuidados, tratamentos e qualidade de vida no melhor do possível para que esse anjo passasse por nossas vidas trazendo amor e muitas lições. \#VaiComDeusPrincesa \#AnjoDeDeus (UMA, 1 jul 2017). 
Quando uma mãe especial perde um filho, todas outras perdem tbm. \#Luto \#AnyIsabelly Mais um anjinho no céu. (UMA, 27 dez. 2017).

Os posts expõem como há uma narrativa 'divinal' nos textos e discursos das mães, que enxergam os filhos como 'anjos', de modo a conferir uma valorização e evidenciar características virtuosas dessas crianças. Há, também, a construção de uma solidariedade entre essas mulheres, que compartilham não só dicas e experiências comuns no cuidado com os filhos 'especiais' - como elas descrevem -, mas também as dores daquelas que perderam suas crianças. Há a menção a um sofrimento compartilhado 'escrevendo e me tremendo' e o reforço dessa união entre as mulheres não só nos momentos alegres, como também nos momentos de luto ‘quando uma mãe perde um filho, todas as outras perdem também'.

Outros dois posts evidenciam como as mães buscam normalizar a vivência das crianças na sociedade. O post com maior número de reações na página traz um vídeo com dois irmãos idosos com microcefalia (UMA, 16 dez. 2016). O vídeo é filmado pela presidenta da UMA em uma viagem a Caruaru, para "a confraternização dos bebês com microcefalia no agreste pernambucano". Os homens com 66 e 67 anos aparecem no vídeo, enquanto a narradora afirma que eles "são a prova viva que a microcefalia não é o fim", frase usada na descrição do post. Durante pouco mais de três minutos, a mulher afirma que "eles têm as limitações deles como todos nós temos as nossas" e a visita procura acalmar as outras mães. "Alimente o coração de vocês, deixe a ansiedade no pé do Senhor [...], temos que lutar por uma assistência melhor para eles e o resto Deus faz", diz a mulher.

A ideia de que é possível viver acompanha toda a construção do vídeo. Na mesma direção, um longo texto acompanhado de fotos de crianças nas diversas situações do cotidiano (em carrinhos, com brinquedos, com familiares, em ensaios fotográficos) começa com a afirmação em letras maiúsculas: "ELE NÃO É DOENTINHO”.

\begin{abstract}
ELE NÃO É DOENTINHO, pelo contrário, muito saudável, às vezes até mais que você. Ah, para seu conhecimento a MICROCEFALIA não É CONTAGIOSA, não se transmite. Não, ELE NÃO É UM CASTIGO, castigo é ter que conviver com pessoas como você. ELE NÃO TEM PROBLEMINHA, você que tem, quando sua ignorância fala mais alto, quando não sabe respeitar as diferencas. ELE NÃO É COITADINHO, pelo contrario, é muito querido e amado por todos nós. Sim ele ainda não anda, não fala, mas vai fazer tudo que você fez ou faz. Tudo no seu tempo, assim como todas as pessoas. Se você tiver grávida, não precisa ter medo de olhar para ele, se você tem medo de ter um filho especial, você não está preparada para ser mãe. Filho não é aquele smartphone que você comprou e veio com defeito ou não gostou e você quer devolver, consertar ou trocar por outro, pense nisso. 6- Deus nunca erraria em sua escolha, concordam? Leia, se tiver dúvida, pergunte, use a tecnologia, o Google, mas não seja indelicado(a). Estou à disposição para esclarecer as suas dúvidas. Ah, sim, você não é obrigado a saber, verdade, mas eu também não sou obrigada a ouvir seus comentários infelizes. Aliás, a minha única obrigação é te manter informado, assim evitamos muitos aborrecimentos. Ensine seu filho a amar, independente das diferenças. Seu filho não nasceu preconceituoso. A referência dele é você! Meu filho é muito especial pra mim e me sinto especialmente abençoada e feliz na missão de tê-lo como filho, proteger e cuidá-lo, ser seus olhos, boca, braços, pernas e aprender todas as grandes lições de vida que ele me ensina. Feliz de quem tem a permissão de receber um anjo na sua vida. (UMA, 04 fev.2017)
\end{abstract}

Mais uma vez, há a reivindicação pela valorização dessas crianças e a reiteração de suas qualidades e particularidades, bem como o destaque para o afeto e o amor que são dedicados a essas crianças naquele espaço e naquela comunidade. A menção ao divino se apresenta, mais uma vez, marcada pela ideia de que os filhos são uma 'benção', uma dádiva escolhida especialmente para aquela família que, portanto, não pode excluí-la: "Filho não é aquele smartphone que você comprou e veio com defeito ou não gostou e você quer devolver [....] Deus nunca erraria em sua escolha”. É presente, ainda que implicitamente, a ideia de que uma "boa mãe", cujo papel é amar incondicionalmente, aprende a cuidar e a não ter medo disso - "se você tem medo de ter um filho especial, você não está preparada para ser mãe”. 
A reivindicação por inclusão e tratamento igualitário aos filhos é marcada, também, pela defesa de que a educação é uma forma de lutar contra as discriminações, já que é importante se informar e buscar conhecimento sobre a condição de saúde dos filhos. A valorização da informação é acompanhada da exposição de que aquela página de Facebook e a associação são, também, espaços para difusão de informações e esclarecimento de dúvidas.

Há ainda dois posts que denotam articulação das mães na busca por direitos e melhoria da qualidade de vida dos seus filhos. O primeiro traz uma reunião com o governador de Pernambuco, Paulo Câmara (PSB), e outros políticos, cujo texto enfatiza a rotina das mães, "que trabalhavam e deixaram suas atividades". O post segue informando que "nenhuma empresa pública ou privada aceitaria nossa atual condição de vida”. No segundo post, é relatado o encontro com o famoso escritor e médico Augusto Cury. Na postagem, as mães são descritas como mulheres que saíram "de um submundo de desprezo social para protagonizar a história de luta de seus filhos".

\begin{abstract}
A segunda reunião com o governador Paulo Câmara, a primeira-dama, à esquerda, o secretário do Estado, Isaltino Nascimento, e o vice-governador, Raul Henry; à direita o ministro da assistência social, Osmar Terra, e o deputado federal, Augusto Coutinho. Demos ênfase à nossa realidade, que muitas de nossas mães que trabalhavam deixaram suas atividades para se dedicar à intensa rotina das terapias de seus filhos onde nenhuma empresa pública ou privada aceitaria nossa atual condição de vida. Então, propomos uma lei que prestasse uma assistência diferenciada de forma indenizatória às famílias vítimas do Zika vírus, onde desse modo não alteraria as regras atuais do BPC (Benefício de Prestação Continuada), se criaria algo a parte, já que sofremos um descaso público, onde não existiria a barreira da renda nesse caso. A UMA responde aos obstáculos do nosso dia a dia com força de vontade e correndo atrás de uma política pública de verdade. Aqui na UMA é trabalho. (UMA, 28 jul. 2016)
\end{abstract}

Essas formas de mobilização desenvolvidas pelas mães, que, diante do "desprezo social" e da difícil rotina de cuidados com os filhos, estabelecem formas de luta, vão ao encontro de algumas perspectivas teóricas abordadas por autoras feministas. Tronto $(1987 ; 2007)$ defende que a perspectiva do cuidado seja desenvolvida dentro de uma visão voltada para uma mudança política, opondo-se às desigualdades e exclusões existentes. Para a autora, o cuidado deve ser politizado, tornando-se uma premissa fundamental das sociedades democráticas. As assimetrias do cuidado não podem ser vistas, nesse sentido, como insolucionáveis, tendo em vista que a "desigualdade pode servir como uma justificativa para continuar a excluir as pessoas que recebem os cuidados e aquelas que os fornecem, e não pensar nelas como cidadãos altamente participativos" (TRONTO, 2007, p. 296-297). Essa mudança política a partir do cuidado envolve, entre outros pontos, o reconhecimento dos sujeitos dependentes do cuidado enquanto cidadãos.

Essa defesa é recorrente em diferentes posts da UMA, principalmente a partir de uma busca por ressignificar a visão dos filhos enquanto 'coitadinhos', 'doentinhos' ou como castigos. As formas de ação da associação e as narrativas adotadas nos posts revelam que as formas de resistência dessas mulheres perpassam, entre outros pontos, pela valorização de seus filhos enquanto sujeitos e pela luta para que eles - e elas, as mães - sejam incluídos e tenham o pleno acesso a direitos.

\title{
CONSIDERAÇÕES FINAIS
}

Neste artigo buscamos observar as falas públicas de mulheres sobre Zika vírus e microcefalia em dois espaços comunicacionais distintos: em um jornal on-line (Folha de S.Paulo) e na página da associação criada por um grupo de mulheres (UMA).

Estamos ancoradas na discussão feminista que diagnostica uma histórica desigualdade e exclusão externa e interna vivenciada por mulheres, no que diz respeito à legitimidade de essas mulheres terem suas experiências e vozes visíveis e consideradas no espaço público (YOUNG, 2000; ROSS, 2010). Nosso 
levantamento quantitativo de 176 notícias publicadas entre novembro de 2015 e janeiro de 2016 no jornal aponta que as mulheres foram ouvidas em apenas 25 textos. Ao observarmos os discursos disponíveis nesse recorte do jornalismo, as desigualdades de forma interseccional (raciais, regionais e financeiras) e as dinâmicas de cuidado que sobrecarregam as mulheres, bem como o temor das gestantes e mães sobre a doença, foram os discursos recorrentes. Já na página do Facebook, a tentativa de normalização da vida das crianças pelas mães, a busca por melhores condições de tratamento e a articulação política para a conquista de direitos específicos são evidentes. As relações de cuidado também são visíveis nesses textos das 'mães de anjos', que encaram a maternidade das crianças com microcefalia como uma tarefa divina e uma espécie de provação com ensinamentos.

No corpus analisado, também chamam a atenção dois pontos pouco explorados. A preocupação com a saúde das mães (e não apenas a das crianças) apareceu em apenas um dos textos. Trata-se de uma pesquisa sobre possíveis sequelas oculares. A notícia informava que: “[...] além das crianças, as mães também passaram por exames oftalmológicos. Queremos entender se as mães foram apenas transmissoras do Zika ou se também tiveram alguma manifestação de infecção do vírus em relação à visão" (NUNES, 2015).

O segundo ponto diz respeito à ausência de um debate sobre aborto e justiça reprodutiva. Entre as matérias coletadas que apresentam mães como fontes diretas, apenas uma cita a palavra aborto, em uma espécie de tira-dúvidas, em que categoricamente é dito que, nos casos de microcefalia, não há a permissão legal. De acordo com o texto: "[...] por não estar previsto em lei, o aborto de fetos com microcefalia e que simultaneamente carreguem má-formações incompatíveis com a vida deve ser autorizado previamente pela Justiça" (SANT’ANNA, 2015). A discussão sobre essa possibilidade é encerrada nesse pequeno trecho. As mulheres não chegam a emitir falas sobre desejo de interrupção da gravidez, entretanto não é possível dizer se foram questionadas sobre isso. No universo dos 176 textos coletados, o debate sobre aborto é levantado, sobretudo a partir de profissionais da saúde, especialistas e juristas, mas sem a presença das mulheres.

Por fim, entendemos que a discussão em torno do tratamento da mídia em relação às mulheres afetadas pela epidemia do Zika e pela microcefalia em seus filhos e filhas envolve fatores complexos e interseccionais que não conseguimos alcançar em sua totalidade neste artigo. Entendemos que reflexões que envolvam uma abordagem feminista da deficiência podem apontar que, se já são poucas as possibilidades de expressão das mulheres sobre o tema, o quadro torna-se ainda mais invisibilizado para mulheres que experienciam deficiências.

Reconhecemos que a ausência desse debate seja uma limitação deste trabalho, e, ao mesmo tempo, um caminho para novas pesquisas, que abarquem discussões sobre deficiências e feminismos (MATOS; SILVA, 2020). Para trabalhos futuros, também consideramos ser relevante investir em análise de imagens. As fotografias dos jornais, com mães de costas, olhares de sofrimento, bebês com rostos escondidos são diferentes daquelas expostas na página da associação, com crianças vivendo um cotidiano característico da infância.

\section{REFERÊNCIAS}

ALVAREZ, Sonia. Para além da sociedade civil: reflexões sobre o campo feminista. Cadernos Pagu, Campinas, v. 43, p. 13-56, jul.-dez. 2014. DOI: https://doi.org/10.1590/0104-8333201400430013. Disponível em: https:// www.scielo.br/j/cpa/a/9Y7dMKrDrFSGDyCJLW45Gpw/abstract/?lang=pt. Acesso em: 10 jun. 2021.

BERNARDINO-COSTA, Joaze. Decolonialidade e interseccionalidade emancipadora: a organização política das trabalhadoras domésticas no Brasil. Sociedade e Estado, Brasília, DF, v. 30, n. 1, p. 147-163, 2015. DOI: https://doi.org/10.1590/S0102-69922015000100009. Disponível em: https://www.scielo.br/j/se/al tjznDrswW4TprwsKy8gHzLQ/?lang=pt. Acesso em: 10 jun. 2021.

BIROLI, Flávia. Gênero e desigualdades: limites da democracia no Brasil. São Paulo: Boitempo, 2018. 
BRASIL. Ministério da Saúde. Secretaria de Vigilância em Saúde. Síndrome Congênita Associada à Infecção pelo vírus Zika: situação epidemiológica, ações desenvolvidas e desafios, 2015 a 2019. Boletim Epidemiológico, Brasília, DF, v. 50, n. esp., p. 1-31, nov. 2019. Disponível em: https://portalarquivos2.saude. gov.br/images/pdf/2019/dezembro/05/be-sindrome-congenita-vfinal.pdf. Acesso em: 12 fev. 2021.

BRASIL. Ministério da Saúde. Secretaria de Vigilância em Saúde. Situação epidemiológica da Síndrome Congênita associada à infecção pelo vírus Zika, 2015 a 2020. Boletim Epidemiológico, Brasília, DF, v. 52, n. 4, p. 15-24, fev. 2021. Disponível em: https://www.gov.br/saude/pt-br/media/pdf/2021/fevereiro/11/boletim epidemiologico_svs_4.pdf. Acesso em: 12 fev. 2021.

BRASIL, Patrícia; PEREIRA JR, José P.; MOREIRA, Elisabeth; NOGUEIRA, Rita M. Ribeiro et al. Zika virus infection in pregnant women in Rio de Janeiro. The New England Journal of Medicine, [s. I.], v. 375, p. 23212334, dez. 2016. Disponível em: https://www.nejm.org/doi/full/10.1056/NEJMoa1602412. Acesso em: 10 jan. 2021.

CANCIAN, Natália; ANIZIELLI, Eduardo. Pensei que fosse efeito de algo que comi, diz mãe de bebê com microcefalia. Folha de S.Paulo, São Paulo, 18 nov. 2015. Cotidiano. Disponível em: https://www1.folha.uol. com.br/cotidiano/2015/11/1707846-pensei-que-fosse-efeito-de-algo-que-comi-diz-mae-de-bebe-commicrocefalia.shtml. Acesso em: 10 jun. 2021.

CARNEIRO, Sueli. Enegrecer o feminismo: a situação da mulher negra na América Latina a partir de uma perspectiva de gênero. In: ASHOKA EMPREENDENDORES SOCIAIS. Racismos contemporâneos. Rio de Janeiro: Takano Editora, 2003, p. 49-58.

CARNEIRO, Sueli. Racismo, sexismo e desigualdade no Brasil. São Paulo: Selo Negro, 2015.

CARVALHO, Layla. Vírus Zika e direitos reprodutivos entre as políticas transnacionais, as nacionais e as ações locais. Caderno Gênero e Diversidade, Salvador, v. 3, n. 2, p. 134-157, maio-ago. 2017. DOI: http:// dx.doi.org/10.9771/cgd.v3i2.22030. Disponível em: https://periodicos.ufba.br/index.php/cadgendiv/article/ view/22030. Acesso em: 6 jan. 2021.

CARVALHO, Layla Pedreira; ELIAS, Maria Ligia G.G.R. Um passo além dos Direitos Humanos das mulheres: a perspectiva da justiça reprodutiva nos casos de esterilização das mulheres e do vírus Zika. In: ENCONTRO DA ABCP, 12., 18-21 ago. 2020, João Pessoa. Anais [...]. João Pessoa: Universidade Federal da Paraíba, 2020.

CASTILHOS, Washington; ALMEIDA, Carla. Discursos sobre o aborto na epidemia de Zika: análise da cobertura dos jornais O Globo e Folha de S.Paulo. Cadernos de Saúde Pública, Rio de Janeiro, v. 36, supl. 1, e00190518, 2020. DOI: https://doi.org/10.1590/0102-311X00190518. Disponível em: https://www.scielo. br/j/csp/a/45p4ZrntPxJrj4WPRNTgkZh/?lang=pt. Acesso em: 10 jun. 2021.

COLLINS, Patricia Hill. Intersectionality as critical social theory. Durham: Duke University Press, 2019.

COLLUCCI, Claudia. Medo da microcefalia faz grávidas repetirem exames sem necessidade. Folha de S.Paulo, São Paulo, 29 nov. 2015. Cotidiano. Disponível em: http://www1.folha.uol.com.br/ cotidiano/2015/11/1712575-medo-da-microcefalia-faz-gravidas-repetirem-exames-sem-necessidade. shtml. Acesso em: 12 fev. 2021.

COLLUCCI, Claudia. “- Por que não comigo?”, pergunta mãe de bebê com microcefalia. Folha de S.Paulo, São Paulo, 4 dez. 2015. Cotidiano. Disponível em: http://www1.folha.uol.com.br/cotidiano/2015/12/1714837mae-de-garota-com-microcefalia-diz-que-ira-investir-em-reabilitacao.shtml. Acesso em: 12 fev.2021

CORREAA, Sonia; PETCHESKY, Rosalind. Direitos sexuais e reprodutivos: uma perspectiva feminista. Physis: Revista de Saúde Coletiva, Rio de Janeiro, v. 6, n. 1-2, p. 147-177, 1996. DOI: https://doi.org/10.1590/ S0103-73311996000100008. Disponível em: https://www.scielo.br/j/physis/a/K7L76NSSqymrLxfsPz8y87F/ abstract/?lang=pt. Acesso em: 10 jun. 2021.

COSTA, Camila. Mãe de adolescentes com microcefalia ajuda nova geração a desafiar limites. Folha de S.Paulo, São Paulo, 12 jan. 2016. Cotidiano. Disponível em: http://www1.folha.uol.com.br/ cotidiano/2016/01/1728531-mae-de-adolescentes-com-microcefalia-ajuda-nova-geracao-a-desafiarlimites.shtml. Acesso em: 12 fev. 2021.

CRENSHAW, Kimberlé. A intersecionalidade na discriminação de raça e gênero. Brasília, DF: Unifem, 2004, p. 7-16. Disponível em: https://nesp.unb.br/popnegra/images/library/Kimberle-Crenshaw-Intersecion alidadenadiscriminaoderaaegenero.pdf. Acesso em: 10 jun. 2021. 
CRENSHAW, Kimberlé. Demarginalizing the intersection of race and sex: a black feminist critique of antidiscrimination doctrine, feminist theory and antiracist politics. University of Chicago Legal Forum, Chicago, v. 1989, n. 1, p. 139-167, 1989. Disponível em: https://chicagounbound.uchicago.edu/cgi/ viewcontent.cgi?article=1052\&context=uclf. Acesso em: 10 jun. 2021.

DINIZ, Debora. Zika em Alagoas: a urgência dos direitos. Brasília, DF: Letras Livres, 2017.

DUARTE, Jorge (org.). Assessoria de imprensa e relacionamento com a mídia: teoria e técnica. 3. ed. São Paulo: Atlas, 2010.

FAIRCLOUGH, Norman. Discurso e mudança social. Brasília, DF: Ed. UnB, 2001.

FRASER, Nancy. Rethinking the public sphere: a contribution to the critique of actually existing. Social Text, Durham, n. 25/26, p. 56-80, 1990. DOI: https://doi.org/10.2307/466240. Disponível em: https://www.jstor.org/ stable/466240. Acesso em: 10 jun. 2021.

GALLAGHER, Margaret. Gender setting: news agendas for media monitoring and advocacy. Londres: Zed Books, 2001.

GILL, Rosalind. Análise do discurso. In: BAUER, Martin; GASKELL, George (ed.). Pesquisa qualitativa com texto, imagem e som: um manual prático. Petrópolis: Vozes, 2002. p. 244-271.

GONZALEZ, Lélia. Racismo e sexismo na cultura Brasileña. In: SILVA, Luiz Antonio; ZICCARDI, Alícia; NUNES, Edison; JACOBI, Pedro et al. Movimentos sociais urbanos, minorias étnicas e outros estudos. ANPOCS, Brasília, 1984. p. 223-344.

GRANGNANI, Juliana. Contra Zika, grávidas mudam rota do Réveillon e estocam repelente. Folha de S.Paulo, São Paulo, 20 dez. 2015. Cotidiano. Disponível em: http://www1.folha.uol.com.br/ cotidiano/2015/12/1721281-contra-zika-gravidas-mudam-rota-do-reveillon-e-estocam-repelente.shtml. Acesso em: 12 fev. 2021.

HIRATA, Helena. O trabalho do cuidado (care) em perspectiva comparada: França, Japão e Brasil. In: ABREU, Maria Aparecida Azevedo. Redistribuição, reconhecimento e representação: diálogos sobre igualdade de gênero. Brasília: Ipea, 2011, p. 84-107.

HIRATA, Helena. O trabalho de cuidado. Sur: revista internacional de direitos humanos, São Paulo, v. 13, n. 24, 2016, p. 53-64. Disponível em: https://sur.conectas.org/o-trabalho-de-cuidado/. Acesso em: 14 jun. 2021.

JÁUREGUI, Carlos; VIEIRA, Vanrochris. Discurso. In: FRANÇA, Vera Veiga; MARTINS, Bruno Guimarães; MENDES, André Melo (org.). Trajetórias, conceitos e pesquisa em comunicação. Belo Horizonte: Selo PPGCOM UFMG, 2014, p. 71-76.

LAGE, Nilson. A reportagem: teoria e técnica de entrevista e pesquisa jornalística. Rio de Janeiro: Record, 2001.

MATOS, Silvana Sobreira; SILVA, Ana Cláudia Rodrigues da. "Nada sobre nós sem nós": associativismo, deficiência e pesquisa científica na Síndrome Congênita do Zika vírus. Ilha Revista de Antropologia, Florianópolis, v. 22, n. 2, p. 132-168, 2020. DOI: https://doi.org/10.5007/2175-8034.2020v22n2p132 Disponível em: https://periodicos.ufsc.br/index.php/ilha/article/view/67659. Acesso em: 10 jul. 2021.

MAIA, Rousiley. Redes cívicas e internet: efeitos democráticos do associativismo. In: GOMES, Wilson; MAIA, Rousiley. Comunicação e democracia: problemas e perspectivas. São Paulo: Paulus, 2008, p. 327-348.

MELO, Patricia Campos. Fundação referência em microcefalia sofre sem repasses em PE. Folha de S.Paulo, São Paulo, 29 jan. 2016. Cotidiano. Disponível em: http://www1.folha.uol.com.br/ cotidiano/2016/01/1734866-fundacao-referencia-em-microcefalia-sofre-sem-repasses-em-pe.shtml.

MIGUEL, Luis Felipe; BIROLI, Flavia. Caleidoscópio convexo: mulheres, política e mídia. São Paulo: Unesp, 2011.

MOREIRA, Martha Cristina Nunes; MENDES, Corina Helena Figueira; NASCIMENTO, Marcos. Zika, protagonismo feminino e cuidado: ensaiando zonas de contato. Interface - Comunicação, Saúde, Educação, Botucatu, v. 22, n. 66, p. 697-708, jul.-set. 2018. DOI: https://doi.org/10.1590/1807-57622017.0930. Disponível em: https://www.scielo.br/j/icse/a/hkSDs3xt7QYvDtCrwbKpdJf/abstract/?lang=pt. Acesso em: 10 jun. 2021. 
NUNES, Kleber. Bebês com microcefalia são avaliados em mutirão no Recife. Folha de S.Paulo, São Paulo,14 dez. 2015. Cotidiano. Disponível em: http://www1.folha.uol.com.br/cotidiano/2015/12/1719043bebes-com-microcefalia-sao-avaliados-em-mutirao-no-recife.shtml. Acesso em: 12 fev. 2021.

NUNES, Kleber. Pernambuco tem falta de psicólogos para mães de bebês com microcefalia. Folha de S.Paulo, São Paulo. Cotidiano. 28 jan. 2016. Cotidiano. Disponível em: http://www1.folha.uol.com.br/ cotidiano/2016/01/1734375-pernambuco-tem-falta-de-psicologos-para-maes-de-bebes-com-microcefalia. shtml. Acesso em: 12 fev. 2021.

PAIXÃO, Patrícia. Linha editorial no jornalismo brasileiro: conceito, gênese e contradições entre a teoria e a prática. Revista Alterjor, São Paulo, v. 17, n. 1, p. 90-108, 2018. Disponível em: https://www.revistas.usp.br/ alterjor/article/view/137224. Acesso em: 10 jun. 2021.

PAN AMERICAN HEALTH ORGANIZATION (PAHO). Epidemiological alert: neurological syndrome, congenital malformations, and Zika virus infection. Implications for public health in the Americas. [S. I.]: PAHO, 2015. Disponível em: https://www.paho.org/hq/dmdocuments/2015/2015-dec-1-cha-epi-alert-zika-neurosyndrome.pdf. Acesso em: 10 jan. 2021.

PATEMAN, Carole. O contrato sexual. São Paulo: Paz e Terra, 1993.

PORTO, Rozeli Maria; COSTA, Patricia Rosalba Salvador Moura. O corpo marcado: a construção do discurso midiático sobre Zika vírus e microcefalia. Cadernos de Gênero e Diversidade, Salvador, v. 3, n. 2, 2017 , p.158-191. DOI: http://dx.doi.org/10.9771/cgd.v3i2.22125. Disponível em: https://periodicos.ufba.br/index. php/cadgendiv/article/view/22125. Acesso em: 10 jun. 2021.

REIS, Julio. Aliviado, casal descobre em mutirão na BA que filha não tem microcefalia. Folha de S.Paulo, São Paulo, 6 dez. 2015. Cotidiano. Disponível em: http://www1.folha.uol.com.br/cotidiano/2015/12/1715672aliaviado-casal-descobre-em-mutirao-na-ba-que-filha-nao-tem-microcefalia.shtml. Acesso em: 12 fev. 2021.

ROSS, Loretta J. Reproductive Justice as Intersectional Feminist Activism. Souls, Chicago, v. 19, n. 3, p. 286314, 2017. DOI: https://doi.org/10.1080/10999949.2017.1389634. Disponível em: https://www.tandfonline. com/doi/abs/10.1080/10999949.2017.1389634?journalCode=usou20. Acesso em: 10 jun. 2021.

ROSS, Karen. Gendered media: women, men, and identity politics. Maryland: Rowman \& Littlefield Publishers, 2010.

SANT'ANNA, Emilio. Exército vai às ruas no Recife em busca de focos do mosquito do Zika. Folha de S.Paulo, São Paulo, 8 dez. 2015. Cotidiano. Disponível em: https://www1.folha.uol.com.br/paywall/login. shtml?https://www1.folha.uol.com.br/cotidiano/2015/12/1716222-exercito-vai-as-ruas-no-recife-em-buscade-focos-do-mosquito-do-zika.shtml. Acesso em: 12 fev. 2021.

SARMENTO, Rayza. Estudos feministas de mídia e política: uma visão geral. BIB - Revista Brasileira de Informação Bibliográfica em Ciências Sociais, São Paulo, n. 87, p. 181-202, 2018. Disponível em: https:// www.anpocs.com/index.php/bib-pt/bib-87/11598-estudos-feministas-de-midia-e-politica-uma-visao-geral/ file. Acesso em: 10 jun. 2021.

SCOTT, James C. Domination and the arts of resistance: Hidden transcripts. Yale University Press, 1990.

TEIXEIRA, Gracimary Alves; DANTAS, Dândara Nayara Azevêdo; CARVALHO, Gleyce Any Freire de Lima; SILVA, Aylla Nauana da et al. Análise do conceito síndrome congênita pelo Zika vírus. Ciência \& Saúde Coletiva, Rio de Janeiro, v. 25, n. 2, p. 567-574, fev. 2020. DOI: http://dx.doi. org/10.1590/1413-81232020252.30002017. Disponível em: https://www.scielo.br/j/csc/a/ Hw7b8hsPTbJncZkwWCmj8Cq/?lang=pt. Acesso em: 10 jun. 2021.

TRONTO, Joan. Beyond gender difference to a theory of care. Signs: journal of women in culture and society, v. 12, n. 4, p. 644-663, 1987. Disponível em: https://www.jstor.org/stable/3174207. Acesso em: 10 jun. 2021.

TRONTO, Joan. Assistência democrática e democracias assistenciais. Sociedade e Estado, Brasília, DF, v. 22, n. 2, p. 285-308, 2007. DOI: https://doi.org/10.1590/S0102-69922007000200004. Disponível em: https:// www.scielo.br/j/se/a/r8ZmgZVYSX9q4PQmYcFkBmK/abstract/?lang=pt. Acesso em: 10 jun. 2021. 
UNIÃO DE MÃES DE ANJOS (UMA). A dor e as incertezas de ser uma mãe especial tem disso... [...]. [S. I.], 1 jul. 2017. Facebook: uniaodemaesdeanjos. Disponível em: https://www.facebook. com/184760061895343/posts/443072839397396/. Acesso em: 10 jun. 2021.

UNIÃO DE MÃES DE ANJOS (UMA). Ele não é doentinho... [S. I.], 4 fev.2017. Facebook: uniaodemaesdeanjos. Disponível em: https://www.facebook.com/184760061895343/ posts/372377366466944l. Acesso em: 12 fev. 2021.

UNIÃO DE MÃES DE ANJOS (UMA). Informações adicionais. [S. I.], c2019. Facebook: uniaodemaesdeanjos. Disponível em: https://www.facebook.com/uniaodemaesdeanjos/about/?ref=page internal. Acesso em: 20 ago. 2019.

UNIÃO DE MÃES DE ANJOS (UMA). Irmãos com Microcefalia de 66 e 67 anos em Caruaru. [S. I.], 16 dez. 2016. Facebook: uniaodemaesdeanjos. Disponível em: https://www.facebook.com/uniaodemaesdeanjos/ videos/347945088910172/. Acesso em: 12 fev. 2021.

UNIÃO DE MÃES DE ANJOS (UMA). Quando uma mãe especial perde um filho, todas outras perdem tbm. [S. I.], 26 dez. 2017. Facebook: uniaodemaesdeanjos. Disponível em: https://www.facebook. com/184760061895343/posts/513153722389307/. Acesso em: 10 jun. 2021.

UNIÃO DE MÃES DE ANJOS (UMA). Reunião com o governador... [S. I.], 28 jul. 2016.

Facebook: uniaodemaesdeanjos. Disponível em: https://www.facebook.com/184760061895343/ posts/275890049449010/. Acesso em: 12 fev. 2021.

WERNECK, Jurema. Racismo institucional e saúde da população negra. Saúde e Sociedade, São Paulo , v. 25, n. 3, p. 535-549, 2016. DOI: https://doi.org/10.1590/S0104-129020162610. Disponível em: https://www. scielo.br/j/sausoc/a/bJdS7R46GV7PB3wV54qW7vm/?lang=pt. Acesso em: 10 jun. 2021.

YOUNG, Iris. La justicia y la política de la diferencia. Ediciones Cátedra: Universitat de Valencia, 1990.

YOUNG, Iris. Inclusion and democracy. Oxônia: Oxford Press, 2000. 